\title{
SYNTHESES OF NOVEL FLUOROQUINOLONE COMPOUNDS
}

\author{
Jianyong $\mathrm{Li}^{\star \text { a, b }}$, Runhua Lu ", , Aimei Yang ", Jiyu Zhang ${ }^{\text {b }}$ \\ a Lanzhou Institute of Chemical Physics, Chincse Academy of Sciences, \\ b* Lanzhou Institute of Animal and Pharmaceutical Veterinary Science, Chinese \\ Academy of Agricultural Sciences, Lanzhou730050, P.R. China, \\ c Chengdu Institute of Biology, Chinese Academy of Sciences \\ *Corresponding author. E-mail:lijy1971@163.com or liiv7112@hotmail.com
}

\begin{abstract}
A series of 1-substituted-6-fluoro-7-(1-(4-((Z)-2-(2-aminothiazol -4-yl)-2-methoxyi-minoacetyl)piperazinyl))-1,4-dihydro-4-oxo-3-quinoline carboxylic acid has been prepared and evaluated for antibacterial activity. These compounds were prepared by the combination of 1-substituted- 6-fluoro-7- piperazinyl- 1,4-dihydro- 4-oxo-3-quinolinecarboxylic acid and S-2-benzo- thiazoyl-(Z)-2-(2-aminathiazol-4-yl)-2-methoxyimino acetate(MAEM) under the condition of Schotten-Baumann. The title compounds are confirmed with NMR,UV, IR, FAB-MS, et al.
\end{abstract}

\section{Introduction:}

The fluoroquinolones are a series of synthetic antibacterial agents that are undergoing extensive investigation for both human and veterinary use in the treatment of a variety of bacterial infections. These agents work through the inhibition of DNA gyrase, interfering with the supercoiling of bacterial chromosomal material. As a result, these agents are rapidly bactericidal primarily against gram-negative bacteria, mycoplasma, and some gram-positive bacteria, with most having little to no activity against group D streptococci and obligate anaerobic bacteria ${ }^{1-4}$. Some quinolones are light toxic or only against some organisms, ct al. Others arc short in half-life and low in bioavailability. Structure modification in applied quinolones is a way in which novel bactericidal quinolones are explored ${ }^{5-8}$. 7-substituted groups in fluoroquinolones agents are of great effect on their bactericidal activity in that 7-substituted groups are correlative to their pharmacokinetics in body and their penetrations into cell of bacteria and affinity to DNA ${ }^{9}$. Pefloxacin becomes more soluble in lipid and more bactericidal in body, while it derives from $\mathrm{N}$-methyl reaction in piperazinyl of norfloxacin ${ }^{10}$. By the reaction of the fluoroquinolone compounds with chlorides of the acid, the chloro-carbonic ester under the condition of Schotten-Baumann, novel $\mathrm{N}$-acyl-piperazinyl-fluoroquinolone compounds were synthesized" ${ }^{\prime \prime}$ S-2-benzothiazoyl -(Z)-2-(2-aminothiazol-4-yl)-2-methoxyimino acetate (MAEM) is an active ester in acylation, a commercially available reagent used as synthesizing cefotaxime ${ }^{12}$.

Herein we report on the most relevant results of our work in this area included in the development of one of our Drug Discovery Programs. Synthetic route to three novel compounds of the 1-substituted-6-substituted-7-piperazinyl-1,4-dihydro-4-oxo-quinoline- 
3-carboxylic Acid modified in 7-position with MAEM is described. General procedure follows as Scheme 1.

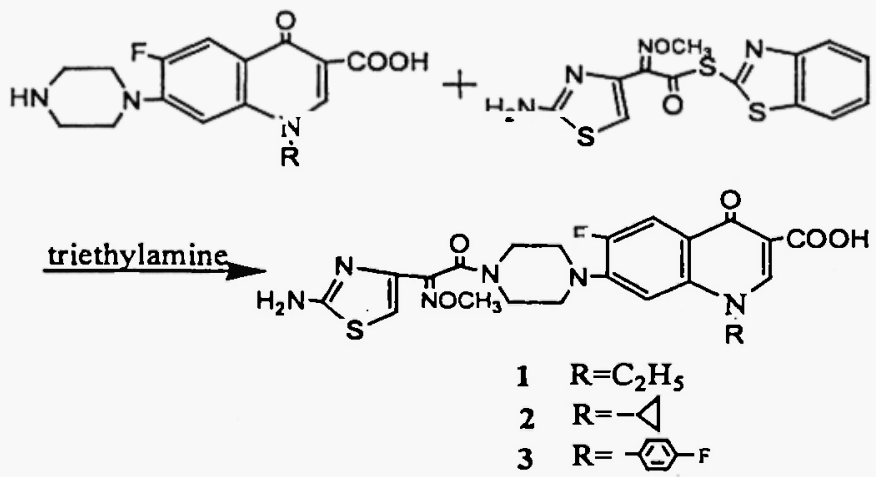

Scheme 1 Synthesis of 7-( (4-acyl ) piperazinyl )fluoro-quinolones $(1,2,3)$.Reagents and conditions: (1) 95\% ethyl acohol, triethylamine, 4h, (2) $\mathrm{HCl}$ (until $\mathrm{PH}=2-3$ ), (3) DMF ( recrystalized)

Fluoroquinolones as starting materials are supplied in market or synthesized in laboratory and they are of great significance against pathogenic bacteria. They have a piperazinyl substitute in 7- position. Both of fluoroquinolones and MAEM are insoluble in water, so selection in appropriate solvents is very important. Literature ${ }^{13}$ in process of preparing cephalosporin compounds from reactive organic acid derivatives described several solvents such as ethyl alcohol, tetrahydrofuran, water and sodium hydrogen carbonate, et al. Moreover, the products in these solvents are generally purer so that many troubles in sequential purification are simplified. The experimental selected enough $95 \%$ ethyl alcohol as solvent, and in the later phase of reaction, concentrated hydrochloric acid diluted with $95 \%$ ethyl alcohol was added until $\mathrm{PH}=2-3$ in liquid. The certification of the title compounds is finished with NMR, UV, FT-IR, FAB-MS. For the title compounds regarded as the recombination of (Z)-2-(2-aminothiazol-4-yl) -2-methoxyimino acetyl and fluoroquinolone, reference to the structural characteristic in cefotaxime and fluoroquinolone ${ }^{14}$ can be very easy to confirm them. Above the synthetic route, in additional to norfloxacin, ciprofloxacin and sarafloxacin, quinolone compounds include nalidixic acid and oxolinic acid with 7-piperazinyl. Their structural formula follows as Figure 1. $\mathrm{X}$ is $\mathrm{N}$ or $\mathrm{C}-\mathrm{F} ; \mathrm{Y}$ is $\mathrm{C}-\mathrm{R}_{\mathrm{l}}, \mathrm{N}$ or cyclic structure linked to 1-positon; $\mathrm{R}$ is alkyl derivatives, $\mathrm{Ar}$ or Cyclic structure linked to 8-positon. In mechanism, these quinolone compounds react with MAEM completely. The conclusion needs confirming.

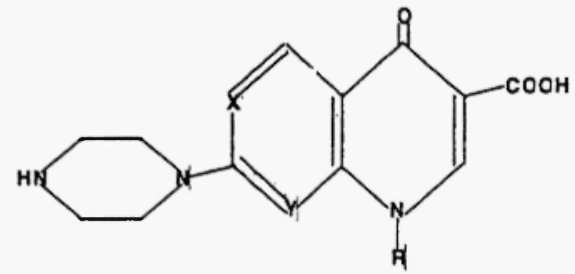

Figure 1 structural formula:

$\mathrm{X}=\mathrm{N}$ or $\mathrm{C}-\mathrm{F}$;

$\mathrm{Y}=\mathrm{C}-\mathrm{R}_{1}, \mathrm{~N}$ or Cyclic structure linked to 1-position;

$\mathrm{R}=$ alkyl derivatives, $\mathrm{Ar}$ or Cyclic structure linked to 8-position 
The comparative in vitro activities of the fluoroquinolones $1,2,3$ showed them to be 4-fold less active in vitro, against both Gram-positive and Gram -negative organisms than their starting materials in reaction. A manuscript detailing the comparative biological activities of these compounds and 7 -((4-acyl) piperazinyl) fluoroquinolones will be published in a later date.

\section{EXPERIMENTAL}

Melting points were determined on XT-4 binocular microscope melting point apparatus (Beijing Tech Instrument Co. Ltd.) and are uncorrected. Proton magnetic resonance (NMR) is determined at $400 \mathrm{MHz}$ with a Varian INOVA 400 spectrometer. The chemical shift values are expressed in $\delta$ values relative to the internal standard tetramethylsilane. Mass spectra ware recorded on a ZAB-HS spectrometer. The IR spectra were determined on Thermo Nicolet Nexus FTIR-470 Spectrometer for $\mathrm{KBr}$ pellets. The UV spectra were determined on UV-240 Spectrophotometer (shimadzu).

\section{Generaī procedure to synthesis of 7-((4-acyl) piperazinyl)fluoroquinolones.}

To $95 \%$ ethyl alcohol $(80 \mathrm{ml})$ in a $250 \mathrm{ml}$-round flask were successively added quinolones $(0.005 \mathrm{~mol})$ and MAEM $1.965 \mathrm{~g}(0.0055 \mathrm{~mol})$ with stirring. After adding triethylamine $1.5 \mathrm{ml}(0.01 \mathrm{~mol})$, the mixture was stirred for 3-5hours while maintaining the temperature of 20 to $25^{\circ} \mathrm{C}$ and then concentrated hydrochloric acid $(0.7 \mathrm{~mL})$ diluted with $95 \%$ ethyl alcohol $(10 \mathrm{~mL})$ was added thereto. The mixture vigorously stirred for about one hour to precipitate thoroughly the crystals. The precipitated crystals filtered, washed with water and then dried to obtain a white solid. The solid was recrystalized in DMF as the title compound.

\section{1-Cyclopropyl-6-fluoro-7-(1-(4-((Z)-2-(2-aminothiazol-4-yl)-2-methoxyiminoacetyl)piperazin} yl))-1,4- dihydro- 4-oxo-3-quinolinecarboxylic acid (1), yield $2.25 \mathrm{~g}(88 \%)$, pale white crystals, m.p. $308-309^{\circ} \mathrm{C}$. $\lambda_{\max }(\mathrm{DMF}) / \mathrm{nm}: 261,283,315,330 . v_{\max }(\mathrm{KBr}) / \mathrm{cm}^{-1}: 624,709$, 746, 804, 832, 938,1004,1047,1179,1253,1443, 1337,1381,1467,1494,1545, 1630,1658, $1722,3420 . \delta_{\mathrm{H}}\left(\mathrm{DMSO}-\mathrm{d}_{6}\right): 1.173-1.320\left(4 \mathrm{H}, 2 \times \mathrm{m}, 2 \times \mathrm{CH}_{2}\right.$ of cyclopropyl), 3.284-3..868 $\left(9 \mathrm{H}, 2 \times \mathrm{m}, 4 \times \mathrm{CH}_{2}\right.$ of piperizinyl and $\mathrm{CH}$ of cyclopropyl $), 3.871\left(3 \mathrm{H}, \mathrm{s}, \mathrm{OCH}_{3}\right)$, $6.883\left(\mathrm{lH}, \mathrm{s}, \mathrm{S}-\mathrm{CH}=\mathrm{C}\right.$ of thiazolyl), $7.239\left(2 \mathrm{H}, \mathrm{br}, \mathrm{s}, \mathrm{NH}_{2}\right), 7.578(1 \mathrm{H}, \mathrm{d}, \mathrm{J}=7.2 \mathrm{~Hz}, \mathrm{Ar})$, 7.929(1H, d, J=13.2Hz, Ar), 8.659(1H, s, $\left.\mathrm{C}_{2}-\mathrm{H}\right), 15.176(1 \mathrm{H}, \mathrm{s}, \mathrm{COOH})$. FAB-MS: 515.1(M+1). Anal. Calcd for $\mathrm{C}_{23} \mathrm{H}_{23} \mathrm{~N}_{6} \mathrm{O}_{5} \mathrm{SF}: \mathrm{C}, 53.69 ; \mathrm{H}, 4.51 ; \mathrm{N}, 16.34$. Found: C,53.62; H, $4.50 ; \mathrm{N}, 16.41$.

1-Ethyl-6-fluoro-7-(1-(4-((Z)-2-(2-aminothiazol-4-yl)-2-methoxyiminoacetyl)piperazinyl))-1,4 -dihydro-4-oxo-3-quinolinecarboxylic acid (2), yield $2.4 \mathrm{~g}(93 \%)$, pale white crystals, m.p. $292-293^{\circ} \mathrm{C} . \lambda_{\max }(\mathrm{DMF}) / \mathrm{nm}: 261,283,315,330 . v_{\max }(\mathrm{KBr}) / \mathrm{cm}^{-1}: 705,746,806,1004,1050$, $1205,1254,1384,1439,1478,1622,1665,1711,1720 . \delta_{\mathrm{H}}\left(\mathrm{DMSO}_{\mathrm{d}}\right): 1.400(3 \mathrm{H}, \mathrm{t}$, $\mathrm{CH}_{3}$ of $\left.\mathrm{NCH}_{2} \mathrm{CH}_{3}\right), 3.271-3 . .771\left(8 \mathrm{H}, \mathrm{m}, 4 \times \mathrm{CH}_{2}\right.$ of piperizinyl), $3.867\left(3 \mathrm{H}, \mathrm{s}, \mathrm{OCH}_{3}\right)$, 
$4.580\left(2 \mathrm{H}, \mathrm{br}, \mathrm{q}, \mathrm{CH}_{2}\right.$ of $\left.\mathrm{NCH}_{2} \mathrm{CH}_{3}\right), 6.875(1 \mathrm{H}, \mathrm{s}, \mathrm{S}-\mathrm{CH}=\mathrm{C}$ of thiazolyl), $7.205(1 \mathrm{H}, \mathrm{d}, \mathrm{J}=$ $7.2 \mathrm{~Hz}, \operatorname{Ar}), 7.243\left(2 \mathrm{H}, \quad b r, \quad s, \quad \mathrm{NH}_{2}\right), \quad 7.9265(1 \mathrm{H}, \mathrm{d}, \mathrm{J}=13.2 \mathrm{~Hz}, \mathrm{Ar}), 8.952(1 \mathrm{H}, \mathrm{s}$, $\left.\mathrm{C}_{2}-\mathrm{H}\right), 15.314(1 \mathrm{H}, \mathrm{s}, \mathrm{COOH})$; FAB-MS: 503.2(M+1). Anal. Calcd for $\mathrm{C}_{23} \mathrm{H}_{23} \mathrm{~N}_{6} \mathrm{O}_{5} \mathrm{SF}$ : C,52.58; H,4.62; N,16.73. Found: C,52.56; H, $4.70 ; \mathrm{N}, 16.81$.

1-(4-fluoro-benzyl)-6-fluoro-7-(1-(4-((Z)-2-(2-aminothiazol-4-yl)-2-methoxyiminoacetyl)piper azinyl))-1,4-dihydro-4-oxo-3-quinolinecarboxylic acid (3), yield $2.2 \mathrm{~g}$ (72\%), pale white crystals, m.p. $275-276^{\circ} \mathrm{C}$. $\lambda_{\max }$ (DMF)/nm: $261,285,317,330 . v_{\max }(\mathrm{KBr}) / \mathrm{cm}^{-1}: 539,805$, $1005,1049,1218,1253,1329,1380,1461,1499,1622,1661,1727,2932,3060,3364 . \delta_{\mathrm{H}}$ ( DMSO-d $\mathrm{d}_{6}$ ) : $3.047-3.713\left(8 \mathrm{H}, \mathrm{m}, 4 \times \mathrm{CH}_{2}\right.$ of piperizinyl), $3.808\left(3 \mathrm{H}, \mathrm{s}, \mathrm{OCH}_{3}\right), 6.406(1 \mathrm{H}, \mathrm{d}$, $\mathrm{J}=7.2 \mathrm{~Hz}, \mathrm{Ar}-\mathrm{H}), 6.835\left(1 \mathrm{H}, \mathrm{s}, \mathrm{S}-\mathrm{CH}=\mathrm{C}\right.$ of thiazolyl), 7.212(21I, br, s, $\left.\mathrm{NH}_{2}\right), 7.528(2 \mathrm{H}, \mathrm{t}$, Ar-H), 7.780(2H, q, Ar-H), 8.065(1H, d, J=12.8Hz, Ar-H), 8.650(1H, s, C $\left.\mathrm{C}_{2}-\mathrm{H}\right), 15.095(1 \mathrm{H}$, s, $\mathrm{COOH}$ ) . FAB-MS: $569.1(\mathrm{M}+1)$. Anal. Calcd for $\mathrm{C}_{23} \mathrm{H}_{23} \mathrm{~N}_{6} \mathrm{O}_{5} \mathrm{SF}$ : C,54.92; H,3.90; $\mathrm{N}, 14.79$. Found: $\mathrm{C}, 54.82 ; \mathrm{H}, 4.01 ; \mathrm{N}, 14.69$.

\section{Acknowledgements:}

FAB-MS is determined in the center of analysis and determination, department of chemistry, Lanzhou University.

\section{References:}

1. D.T.W. Chu, J.J. Plattner, L. Katz, J. Med. Chem., 1996, 39(7), 3853

2. M.B. Frpsco, L.E. Lawrence, J.F. Barret, Exp. Opin. Invest. Drugs, 1999,8(12),2201

A. Byrskier, Exp. Opin. Invest. Drugs, 1997, 6(4):1227

4. D.T.W. Chu, P.B. Fernandes,Adv. Drug. Res., 1991, 21(1):39

5. R.H. Nanzo, D.H. Allemandi, J.D. Perez, US: 5395936, 1995-03-07

6. C. Perrin, FR: $2706459,1994-12-23$

7. O. Kazumi, EP: $610896,1994-08-17$

8. H.Y. Guo, Y. Tang, Act. Pharm. Sin., 1993, 28(6):477

9. A. Bryskier, J.F. Chantot, Drugs, 1995, 49 (Supl 2):16

10. Hrosato Kondo, Fumio Sakamoto, Kiyotaka Kawakami, et al., J. Med. Chem., 1988, 31(1):221

11. M.C. Tian, L.B. Ou, J.G. Xie, et al., Act.Pharm. Sin., 2002,49(10): 249

12. J. C. Rodriguez, H. Ricardo, G. Maritza, et al., IL FARMACO, 2000,55:393

13. S. K. Kim; J.L. Kim, N. Seong, et al., EP 0628561 Bl, 1997-09-03

14. H. A. Albrecht, G. Beskid, K.K. Chan, et al., J. Med. Chem. 1990,33,77

Received on May 10, 2004. 